\title{
Article/Artigo
}

\section{Hepatitis B marker seroprevalence and vaccination coverage in adolescents in the City of Itajaí, State of Santa Catarina, Southern Brazil, in 2008}

\author{
Soroprevalência de marcadores da hepatite B e cobertura de vacinação em adolescentes no \\ município de Itajaí, Estado de Santa Catarina Sul do Brasil, em 2008
}

\section{Gabriela Chiochetta Tonial ${ }^{1}$, Ana Maria Passos ${ }^{1}$, Andréa do Livramento ${ }^{1}$, Natália Gazzoni Scaraveli ${ }^{1}$, Anna Paula de Borba Batschauer ${ }^{2}$, Ednéia Casagrande Bueno ${ }^{2}$, Álvaro Largura ${ }^{3}$, Celso Spada ${ }^{4}$ and Aricio Treitinger ${ }^{4}$}

\begin{abstract}
Introduction: Hepatitis B infection constitutes an important cause of morbidity and mortality worldwide. In Brazil, however, the current epidemiological situation is not clear. Considering the importance of establishing this prevalence, the aim of this study was to determine the prevalence of HBV markers in voluntary adolescents, junior high (secondary school) students, in the City of Itajaí, State of Santa Catarina, Brazil. Methods: A seroepidemiological, transverse study was conducted with 353 randomly chosen adolescents from elementary school in 2008. Blood samples were analyzed for $\mathrm{HBsAg}$, anti-HBc and anti-HBs. All analyses were conducted by automated microparticle enzyme immunosorbent assay (Abbott ${ }^{\circledR}$, AxSYM system, Deerfield, IL, USA), according to the manufacturer's instructions. Results: The prevalence of HBsAg was $0.6 \%$ (CI 95\% $0.1-2.0)$, that of anti-HBc was $1.1 \%$ (CI 95\% $0.3-2.9)$ and that of detectable anti-HBs was $83.6 \%$ (CI 95\% 79.3 - 87.3). Hepatitis B vaccination coverage was $97.5 \%$ (CI 95\% 95.2 - 98.8). Conclusions: These results demonstrate the success of the vaccination program against hepatitis $B$ in the region studied and indicate that prevention strategies must be maintained and, if possible, expanded to contribute to the establishment of positive prevalence rates in all age groups.
\end{abstract}

Keywords: Hepatitis B. Prevalence. Vaccination.

\section{RESUMO}

Introdução: A hepatite B constitui uma causa relevante de morbidade e mortalidade em todo o mundo. No Brasil, entretanto, a situação epidemiológica atual não é claramente conhecida. Considerando-se a importância do estabelecimento de tal prevalência, o objetivo deste estudo foi determinar a prevalência dos marcadores de HBV em adolescentes voluntários, estudantes do ensino fundamental na Cidade de Itajaí, Santa Catarina, Brasil. Métodos: Trata-se de um estudo soroepidemiológico, transversal, conduzido com 353 adolescentes do ensino fundamental, randomicamente selecionados, em 2008. As amostras de sangue foram analisadas quanto à presença dos marcadores $\mathrm{HBsAg}$, anti-HBc e anti-HBs. Todas as análises foram conduzidas em ensaio imunoenzimático de micropartículas automatizado (Abbott ${ }^{\circledR}$, AxSYM system, Deerfield, IL, EUA), de acordo com as instruções do fabricante. Resultados: A prevalência do HBsAg foi de 0,6\% (CI 95\% 0,1 - 2,0), do anti-HBc foi de 1,1\% (CI 95\% 0,3-2,9) e de títulos detectáveis de anti-HBs foi de $83,6 \%$ (CI 95\% 79,3 - 87,3). A cobertura vacinal nos adolescentes estudados foi de 97,5\% (CI 95\% 95,2 - 98,8). Conclusões: Estes resultados demonstram o sucesso do programa de vacinação contra a hepatite $B$ na região estudada $e$ indicam que as estratégias de prevenção devem ser mantidas e, se possível, expandidas para que contribuam no estabelecimento de taxas de prevalência positivas em todas as faixas etárias. Palavras-chaves: Hepatite B. Prevalência. Vacinação.

1. Programa de Pós Graduação em Farmácia, Universidade Federal de Santa Catarina, Florianópolis, SC. 2. Departamento de Análises Clínicas, Universidade do Vale do Itajaí, Itajaí, SC. 3. Instituto de Investigação Científica do Paraná, Cascavel, PR. 4. Departamento de Análises Clínicas, Centro de Ciências da Saúde, Universidade Federal de Santa Catarina, Florianópolis, SC.

Address to: Dr. Aricio Treitinger. Dept ${ }^{\circ}$ Análises Clínicas/CCS/UFSC. Caixa Postal 476, Campus Universitário, Trindade, 88040-900 Florianópolis, SC, Brasil.

Phone: 5548 3721-9712; Fax: 5548 3721-9542

e-mail: aricio@ccs.ufsc.br

Received in $27 / 11 / 2010$

Accepted in 15/03/2011

\section{INTRODUCTION}

Infections with hepatitis B virus (HBV) represent a significant cause of morbidity and mortality worldwide and constitute a problem of global public health importance ${ }^{1}$.

The World Health Organization (WHO) estimates that, currently, more than two billion individuals among the global population have been infected with $\mathrm{HBV}$ and of these, approximately 360 million are chronically infected ${ }^{2}$.

In Brazil, the prevalence of $\mathrm{HBV}$ is variable, increasing from South to North. Previous studies have indicated a low prevalence rate in southern Brazil, a medium prevalence rate in the Northeast and Southeast, and a high prevalence rate in the Amazon region, State of Espírito Santo, and in the west of the State of Santa Catarina ${ }^{3}$.

However, due to territorial extension, cultural and economic differences in Brazil and since few studies have been conducted among the general population, the current epidemiological situation is not clear.

The elimination of $\mathrm{HBV}$ transmission is achievable through vaccination, clearly the most effective strategy for preventing hepatitis B and hepatocellular carcinoma. The HBV vaccine is now one of the most widely used vaccines in the world ${ }^{4}$. The official immunization schedule in Brazil includes the $\mathrm{HBV}$ vaccine for newborns, children and young adults up to 19 years of age, pregnant women after the first trimester and individuals at risk of $\mathrm{HBV}$ infection ${ }^{5-7}$. Conversely, only minimal data is available concerning the risk factors for HBV infection in Latin American countries, including Brazil $^{8}$, since most studies regarding HBV prevalence in the country are performed in specific groups, such as blood donors ${ }^{9-12}$ or HIV-seropositive patients ${ }^{13,14}$.

It is known that establishing the prevalence of HBV in the general population is crucial to anticipating its future impact on the health system 
and also to ensuring an adequate allocation of financial resources ${ }^{15}$ Thus, the aim of this study was to determine the prevalence of $\mathrm{HBV}$ markers and assess hepatitis B vaccination coverage in voluntary adolescents, junior high (secondary school) students, in the City of Itajaí, State of Santa Catarina, Brazil.

\section{METHODS}

Itajaí is located in the northern coast of the State of Santa Catarina, Southern Brazil and houses the main port in the state.

This cross-sectional study included junior high (secondary school) student volunteers, adolescents aged between 10 and 15 years-old, residents of the City of Itajaí, from April to September 2008.

A random sampling plan was conducted for the selection of volunteers, so that it would reproduce the distribution of the adolescent population in junior high (secondary school) (Brazilian grade 5 to 8 ) in the City of Itajaí, including the administrative category of school attendance (public or private) and their dimensions and geographic locations within the city.

The minimum number of samples was calculated to be statistically representative of the target population and capable of determining HBV prevalences up to $30 \%$, with an admissible error of $5 \%$ and a confidence interval of $95 \%{ }^{16}$. Although the prevalence of these markers in the population studied was unknown, according to the Ministry of Health it is expected to be less than $2 \%^{17}$. Thus, our group overestimated that for this specific group, the prevalence could be up to $30 \%$, to ensure that sample size would not interfere in the results.

Using such criteria the minimum sample number was defined as 322 and by the end of the process, 353 students were enrolled to participate in the study.

A $10 \mathrm{~mL}$ blood sample was collected of each volunteer by venous puncture. Serology comprised $\mathrm{HBsAg}$, anti-HBc and anti-HBs. Samples which tested positive for anti-HBc total were also tested for anti-HBcIgM.Every test was performed using automated microparticle enzyme immunosorbent assay (Abbott ${ }^{\circledR}$, AxSYM System, Deerfield, IL, USA), in accordance with the manufacturer's instructions.

The vaccination coverage assessment was performed by vaccination cards checks in $100 \%$ of the volunteers.

$\mathrm{HBsAg}$ and anti-HBc results were categorized as 'reactive' or 'nonreactive', strictly in accordance with the manufacturer's instructions. The state of HBV infection was defined as reagent anti$\mathrm{HBc}$ in the volunteer, according to the Brazilian Ministry of Health ${ }^{18}$

Anti-HBs titers were categorized as: undetectable (anti-HBs = $0 \mathrm{mIU} / \mathrm{mL})$, detectable $(0 \mathrm{mIU} / \mathrm{mL}<$ anti-HBs $<10 \mathrm{mIU} / \mathrm{mL})$, and reactive (anti-HBs $\geq 10 \mathrm{mIU} / \mathrm{mL}$ ).

Statistical analysis consisted of inferential analysis of data for different proportions. The prevalence of each antibody was defined as the percentage of reagent samples and the $95 \%$ confidence interval (95\% CI) was calculated for each prevalence rate. All data were tabulated and analyzed in the Statistical Package for Social Sciences (SPSS Inc., version 11.0, Chicago, USA).

\section{Ethical considerations}

The study was approved by the Research Ethics Committee of the Federal University of Santa Catarina (Project 284/07). Free, informed consent was obtained from a parent or guardian of each volunteer.

\section{RESULTS}

The age of the participants varied from 10 to 15 years-old, with a mean age of 13.3 years-old and standard deviation of 1.2 years. The distribution of adolescents according to sex and age is shown in Table 1.

Table 2 shows the distribution of HBV serological markers in the sample studied.

HBV vaccine coverage was determined as $97.5 \%$ (CI 95\% 95.2 - 98.8), with $92.1 \%$ (CI 95\% 88.7 - 94.7) receiving the complete vaccination scheme of three doses of the HBV vaccine. Table 3 shows the distribution of the number of vaccine doses received by the adolescents.

TABLE 1 - Distribution of voluntary adolescents from Southern Brazil according to gender and age, 2008.

\begin{tabular}{ccc}
\hline & Number & Percentage \\
\hline Gender & & \\
male & 129 & 36.5 \\
female & 224 & 63.5 \\
Total & 353 & $\mathbf{1 0 0 . 0}$ \\
\hline Age & & \\
$10-11$ & 24 & 6.8 \\
$12-13$ & 157 & 44.5 \\
$14-15$ & 172 & 48.7 \\
Total & 353 & $\mathbf{1 0 0 . 0}$ \\
\hline
\end{tabular}

TABLE 2 - Seroprevalence of HBV markers in voluntary adolescents from Southern Brazil, 2008.

\begin{tabular}{lccc}
\hline HBV markers & Number & Percentage & CI 95\% \\
\hline HBsAg alone & 2 & 0.6 & 0.1 - 2.0 \\
\hline Anti-HBc alone & 4 & 1.1 & $0.3-2.9$ \\
\hline HBsAg/Anti-HBc & 2 & 0.6 & $0.1-2.0$ \\
\hline Anti-HBc/Anti-HBs & 2 & 0.6 & $0.1-2.0$ \\
\hline Anti-HBs $\geq 10 \mathrm{IU} / \mathrm{L}$ alone & 183 & 51.8 & $46.5-57.2$ \\
\hline 0IU/L < anti-HBs < 10IU/L alone & 112 & 31.7 & $26.9-36.9$ \\
\hline Absence of HBV markers & 52 & 14.7 & 11.2 - 18.9
\end{tabular}

HBV: hepatitis B virus, $\mathrm{HBsAg}$ : hepatitis B surface antigen, anti-HBc: hepatitis B core antibody, anti-HBs: hepatitis B surface antibody.

TABLE 3 - Vaccination coverage in voluntary adolescents from Southern Brazil, 2008.

\begin{tabular}{lcc}
\hline Doses of vaccine & Number & Percentage \\
\hline None & 9 & 2.5 \\
\hline One & 8 & 2.3 \\
\hline Two & 11 & 3.1 \\
\hline Three or more & 325 & 92.1 \\
\hline Total & $\mathbf{3 5 3}$ & $\mathbf{1 0 0 . 0}$ \\
\hline
\end{tabular}

\section{DISCUSSION}

In this study, a low prevalence of HBV infection of $1.1 \%$ was verified, similar to that of adolescents and young adults from developed countries, where hepatitis $B$ vaccination programs are fully implemented, such as Italy $(0.9 \%)^{19}$, Spain $(0.9 \%)^{20}$ and the United 
States $(1 \%)^{21}$, and that verified in a nationwide study in northeastern and central-western Brazil $(1.3 \%)^{22}$ and by our group in the metropolitan area of Florianópolis, Santa Catarina, Brazil $(0.5 \%)^{23}$. In contrast, this prevalence is lower than that of Greece $(2.5 \%)^{24}$ and of developing regions, where $\mathrm{HBV}$ vaccination programs are only partially implemented or not implemented at all, such as Mexico $(5 \%)^{25}$, Bolivia $(6.9 \%)^{26}$ and central Brazil $(5.9 \%)^{27}$.

The low prevalence of HBV infection determined in this study indicates a significant reduction in the residual risk of HBV transmission and can be explained by the low rate of vertical and intrafamilial transmission, but can also be attributed to the impact of AIDS campaigns in indirectly decreasing the prevalence of HBV. Moreover, this age group is expected to be less exposed to risk factors of transmission, such as intravenous drug use, blood transfusions and occupational infection ${ }^{20}$.

Additionally, such a low prevalence can also be attributed to recent efforts to vaccinate children against hepatitis in this region. This is justified, at least in part, by the fact that the greater part (92.1\%) of the volunteers received three or more doses of hepatitis $B$ vaccine. Thus, considering that almost half of those who participated in this study were born in the same year as hepatitis B vaccine implementation in the state (1993) or on the following year and considering that although implemented in 1993, it might have taken some time to be fully functional, this rate is very favorable. Additionally, the hepatitis $B$ vaccine coverage verified in this study $(97.5 \%)$ is higher than that expected by the Ministry of Health (95\%) for adolescents and recently achieved for infants under one year old (95\%) in the State of Santa Catarina ${ }^{5,28}$, or at least very similar (considering only those who received the complete vaccination scheme).

In addition to past cured infections, immunity against HBV infection is achieved through vaccination and anti-HBs are responsible for this immunity. Primary vaccination with a three-dose series of hepatitis $B$ vaccine results in seroprotection: defined as the development of anti-HBs at a concentration greater than 10 mille International Units per milliliter $[\mathrm{mIU} / \mathrm{mL}]$ ) in $>95 \%$ of vaccinated infants and children ${ }^{29}$. However, following completion of the primary series, anti-HBs concentrations decline and can fall below $10 \mathrm{mIU} / \mathrm{mL}$ after several years ${ }^{30-33}$.

Several studies discuss the necessity of booster doses of the vaccine for those with detectable anti-HBs titers below $10 \mathrm{mIU} / \mathrm{mL}$. Moreover, certain authors argue that strong immunological memory persists for up to 22 years, once the complete vaccination scheme has been administered properly and therefore, an anamnestic anti$\mathrm{HBs}$ response capable of preventing against chronic or symptomatic infections is achieved after HBV contact, even if anti-HBs titers are not higher than $10 \mathrm{mIU} / \mathrm{mL}^{34-38}$. Therefore, considering that the students were vaccinated up to 15 years ago, we opted to consider as immunized, all individuals previously vaccinated with a three-dose series of hepatitis B vaccine and with detectable anti-HBs titers (anti-HBs $>0 \mathrm{mIU} / \mathrm{mL}$ ). Consequently, it can be affirmed that at least $83.6 \%$ of the volunteers in this study are successfully immunized against $\mathrm{HBV}$.

Although this rate is lower than that of volunteers who have received the primary vaccination with a three-dose series of hepatitis B vaccine $(92.1 \%)$, consideration must be made that the expected gradual decrease in anti-HBs titers over the years may have made them undetectable and that not all the volunteers received the vaccine in the first few years after being born (data not shown) and thus, up to $10 \%$ of those vaccinated may not have developed proper antibody titers, since it has been well established that the rate of seroconversion is approximately $90 \%$ when adolescents and adults are considered ${ }^{39-42}$.

Although the reality described here cannot be extrapolated to older age groups in the region studied, the observations made reveal that a successful vaccination strategy will result in a population of adults protected against $\mathrm{HBV}$, within a few years, with prevalence rates in this age group that are also similar to that of developed countries. This high vaccine coverage will also have an impact on lowering future hepatic cancer rates in this population, thus allowing public health economic resources to be spent in less preventable illnesses.

In conclusion, the results obtained showed a low prevalence of HBV markers of infection in adolescents from Itajaí, State of Santa Catarina, with great vaccination coverage and high prevalence of anti-HBs. These results demonstrate the success of the vaccination program against hepatitis B initiated in 1993 and indicate that this prevention strategy must be maintained and, wherever possible, expanded, while other prevention forms should be developed to prevent HBV transmission and contribute to the establishment of positive prevalence rates in all age groups.

\section{CONFLICT OF INTEREST}

The authors declare that there is no conflict of interest.

\section{FINANCIAL SUPPORT}

The author Ana Maria Passos has been granted a CNPq Scholarship.

\section{REFERENCES}

1. KaoJH, Chen PJ, Lai MY, Chen DS. Occult hepatitis B virus infection and clinical outcomes of patients with chronic hepatitis C. J Clin Microbiol 2002; 40:40684071 .

2. World Health Organization. Hepatitis B vaccines. Wkly Epidemiol Rec 2004;79:255-263.

3. Ministério da Saúde. Doenças Infecciosas e Parasitárias: Guia de Bolso. Brasília: Departamento de Vigilância Epidemiológica; 2004.

4. Shepard CW, Simard EP, Finelli L, Fiore AE, Bell BP. Hepatitis B virus infection: epidemiology and vaccination. Epidemiol Rev 2006; 28:112-125.

5. Ministério da Saúde. Manual de aconselhamento em hepatites virais. Brasília: Departamento de Vigilância Epidemiológica; 2005.

6. Ministério da Saúde. Programa Nacional de Imunizações: PNI 25 anos. Brasília: Fundação Nacional de Saúde; 1998.

7. Ministério da Saúde [Internet]. Ministério da Saúde amplia grupo da vacina da hepatite B [cited Oct 2010]. Available from: http://portal.saude.gov.br/portal/ arquivos/.

8. Gish RG, Gadano AC. Chronic hepatitis B: Current epidemiology in the Americas and implications for management. J Viral Hepat 2006; 13:787-798.

9. Andrade AFB, Silva MO, Silva SGC, Motta IJF, Bonvicino CR. Seroprevalence of hepatitis B and C virus markers among blood donors in Rio de Janeiro, Brazil, 1998-2005. Mem Inst Oswaldo Cruz 2006; 101:673-676.

10. Nascimento MC, Mayaud P, Sabino EC, Torres KL, Franceschi S. Prevalence of hepatitis $\mathrm{B}$ and $\mathrm{C}$ serological markers among first-time blood donors in Brazil: a multi-center serosurvey. J Med Virol 2008; 80:53-57.

11. Treitinger A, Spada C, Ferreira LA, Strazzer Neto M, Reis M, Verdi JC, et al. Hepatitis $\mathrm{B}$ and hepatitis $\mathrm{C}$ prevalence among blood donors and HIV-1 infected patients in Florianópolis-Brazil. Braz J Infect Dis 2000; 4:192-196. 
12. Rosini N, Mousse D, Spada C, Treitinger A. Seroprevalence of HBsAg, anti-HBc and anti-HCV in Southern Brazil, 1999-2001. Braz J Infect Dis 2003; 7:262-267.

13. Treitinger A, Spada C, Silva EL, Miranda AF, Oliveira OV, Silveira MV, et al. Prevalence of serologic markers of HBV and HCV infection in HIV-1 seropositive patients in Florianópolis-Brazil. Braz J Infect Dis 1999; 3:1-5.

14. Pereira RARA, Mussi ADH, Silva VCA, Souto FJD. Hepatitis B virus infection in HIV-positive population in Brazil: results of a survey in the state of Mato Grosso and a comparative analysis with other regions of Brazil. BMC Infect Dis 2006; 6:34.

15. Fabris P, Baldo V, Baldovin T, Bellotto E, Rassu M, Trivello R, et al. Changing Epidemiology of HCV and HBV Infections in Northern Italy: A Survey in the General Population. J Clin Gastroenterol 2008; 42:527-532.

16. Motta VT, Wagner MB. Bioestatística. Caxias do Sul: Educs; 2003.

17. Ministério da Saúde. Secretaria de Vigilância em Saúde. Material instrucional para capacitação em vigilância epidemiológica das hepatites virais. Brasília: Ministério da Saúde; 2008

18. Ministério da Saúde. Hepatites Virais: O Brasil Está Atento. $3^{a}$ ed. Brasília: Ministério da Saúde; 2008.

19. Bonanni P, Pesavento G, Bechini A, Tiscione E, Mannelli F, Benucci C, et al. Impact of universal vaccination programmes on the epidemiology of hepatitis B: 10 years of experience in Italy. Vaccine 2003; 21:685-691.

20. Salleras L, Dominguez A, Bruguera M, Cardeñosa N, Batalla J, Carmona G, et al. Dramatic decline in acute hepatitis $\mathrm{B}$ infection and disease incidence rates among adolescents and young people after 12 years of a mass hepatitis B vaccination programme of pre-adolescents in the schools of Catalonia (Spain). Vaccine 2005; 23:2181-2184.

21. McQuillan GM, Townsend TR, Fields HA, Carroll M, Leahy M, Polk BF Seroepidemiology of hepatitis B virus infection in the United States. 1976 to 1980. Am J Med 1989; 87:5-10

22. Pereira LM, Martelli CM, Merchán-Hamann E, Montarroyos UR, Braga MC, de Lima ML, et al. Population-based multicentric survey of hepatitis B infection and risk factor differences among three regions in Brazil. Am J Trop Med Hyg 2009; $81: 240-247$.

23. Voigt AR, Strazzer Neto M, Spada C, Treitinger A. Seroprevalence of hepatitis B and hepatitis $\mathrm{C}$ markers among children and adolescents in teh south brazilian region - metropolitan area of Florianópolis, Santa Catarina. Braz J Infect Dis $2010 ; 14: 60-65$

24. Gogos CA, Fouka KP, Nikiforidis G, Avgeridis K, Sakellaropoulos G, Bassaris H, et al. Prevalence of hepatitis $B$ and $C$ virus infection in the general population and selected groups in South-Western Greece. Eur J Epidemiol 2003; 18:551-557.

25. Cisneros-Castolo M, Hernandez-Ruiz L, Ibarra-Robles IE, Fernández-Gárate RH, Escobedo-De La Peña J. Prevalence of hepatitis B virus infection and related risk factors in a rural community of Mexico. Am J Trop Med Hyg 2001; 65:759-763.

26. Gandolfo GM, Ferri GM, Conti L, Antenucci A, Marrone R, Frasca AM, et al. Prevalence of infections by A, B, C and $\mathrm{E}$ viruses in two different socioeconomic groups of children from Santa Cruz, Bolívia. Med Clin 2003; 120:725-727.

27. Oliveira MDS, Martins RMB, Matos MA, Ferreira RC, Dias MA, Carneiro MA, et al. Seroepidemiology of hepatitis B virus infection and high rate of response to hepatitis B virus Butang ${ }^{\circledast}$ vaccine in adolescents from low income families in Central Brazil. Mem Inst Oswaldo Cruz 2006; 101:251-256.

28. Ministério da Saúde. Secretaria de Vigilância em Saúde. Sistema nacional de vigilância em saúde: relatório de situação - Santa Catarina. Brasília: Ministério da Saúde; 2007.

29. International Group. Immunization against hepatitis B. Lancet 1988; 1:875-876.

30. Zanetti AR, Mariano A, Romanò L, D’Amelio R, Chironna M, Coppola RC, et al. Long-term immunogenicity of hepatitis $\mathrm{B}$ vaccination and policy for booster: an Italian multicentre study. Lancet 2005; 366:1379-1384.

31. Ferreira CT, Silveira TR. Viral hepatitis prevention by immunization. J. Pediatr 2006; 82 (supl): 55-66.

32. Giambi C, Bella A, Barale A, Montù D, Marchisio M, Oddone M, et al. A cohort study to evaluate persistence of hepatitis B immunogenicity after administration of hexavalent vaccines. BMC Infect Dis 2008; 8:100.

33. Bialek SR, Bower WA, Novak R. Persistence of protection against hepatitis B virus infection among adolescents vaccinated with recombinant hepatitis $\mathrm{b}$ vaccine beginning at birth: a 15-year follow-up study. Pediatr Infect Dis J 2008; $27: 881-885$
34. Hammitt LL, Hennessy TW, Fiore AE, Zanis C, Hummel KB, Dunaway E, et al. Hepatitis $B$ immunity in children vaccinated with recombinant hepatitis $B$ vaccine beginning at birth: a follow-up study at 15 years. Vaccine 2007; 25:6958-6964.

35. But DY, Lai CL, Lim WL, Fung J, Wong DK, Yuen MF. Twenty-two years followup of a prospective randomized trial of hepatitis $B$ vaccines without booster dose in children: final report. Vaccine 2008; 26:6587-6591.

36. McMahon BJ, Dentinger CM, Bruden D, Zanis C, Peters H, Hurlburt D, et al. Antibody levels and protection after hepatitis B vaccine: results of a 22 -year follow-up study and response to a booster dose. J Infect Dis 2009; 200:1390-1396.

37. Poorolajal J, Mahmoodi M, Majdzadeh R, Nasseri-Moghaddam S, Haghdoost A, Fotouhi A. Long-term protection provided by hepatitis B vaccine and need for booster dose: A meta-analysis. Vaccine 2010; 28:623-631.

38. Poovorawan $Y$, Chongsrisawat V, Theamboonlers A, Bock HL, Leyssen M, Jacquet JM. Persistence of antibodies and immune memory to hepatitis B vaccine 20 years after infant vaccination in Thailand. Vaccine 2010; 28:730-736.

39. Arslanoglu I, Cetin B, Isguven P, Karavus M. Anti-HBs response to Standard Hepatitis B vaccination in children and adolescents with diabetesmellitus. J Pediatr Endocrinol Metab 2002; 15:389-395.

40. Cook IF, Murtagh J. Comparative immunogenicity of hepatitis B vaccine administered into the ventrogluteal area and anterolateral thigh in infants. J Paediatr Child Health 2002; 38:393-396.

41. Abraham B, Baine Y, De-Clercq N, Tordeur E, Gerard PP, Manouvriez PL, et al Magnitude and quality of antibody response to a combination hepatitis $\mathrm{A}$ and hepatitis B vaccine. Antiviral Res 2002; 53:63-73.

42. Cassidy WM. Adolescent hepatitis B vaccination. A review. Minerva Pediatr $2001 ; 53: 559-566$ 